\title{
EKSISTENSI MASALAH SUPRANATURAL DALAM FOLKLOR LISAN SASAK: SUATU KAJIAN TEMATIS TERHADAP CERITA RAKYAT SASAK YANG TELAH DIDOKUMENTASIKAN
}

\author{
(THE EXISTENCE OF SUPERNATURAL PROBLEMS IN SASAK ORAL \\ FOLKLORE: A THEMATIC STUDY OF SASAK FOLKTALES THAT HAS BEEN \\ DOCUMENTED)
}

\section{Lalu Fakihuddin}

Program Studi Pendidikan Bahasa dan Sastra Indonesia, STKIP Hamzanwadi Jalan TGKH Zainuddin Abdul Madjid No.132 Pancor 83612, Selong, NTB, Indonesia Pos-el: fakihuddinlalu@yahoo.co.id

Diterima: 1 September 2015; direvisi: 10 Desember 2015; disetujui: 15 Desember 2015

\begin{abstract}
This research is purposed to uncover forms of beliefs of the old-time Sasak people. It encompasses all supernatural things and their existence in the Sasak society now. This research used qualitative research's methods yet descriptive-interpretative. The resources of research's data are specific sequences from Sasak folktales that show Sasak people's beliefs about supernatural things. Methodologically, this research used hermeneutic approach, an approaching technique which tried to interpret a text deeply. The data analysis refers to a perspective-constructivist model, which is directed by intentions, categories that have been set and results that want to be achieved. The results show that in Sasak folktales, there are many beliefs about supernatural things, supernatural beings, or things outside human's logic. Examples of these supernatural things/problems are the holiness of God's holy men (Wali Allah), believing in divine inspirations, presentiments, dreams, and believing in the existence of supernatural beings.
\end{abstract}

Keywords: existence, supernatural, oral folklore, Sasak, thematic study

\begin{abstract}
Abstrak
Penelitian ini bertujuan untuk mengungkap bentuk-bentuk kepercayaan masyarakat Sasak zaman dahulu tentang hal-hal yang bersifat supranatural dan eksistensinya pada masyarakat Sasak saat ini. Penelitian ini menggunakan rancangan penelitian kualitatif yang bersifat deskriptif-interpretatif. Sumber data penelitian ini berupa sekuen-sekuen tertentu dari Cerita Rakyat Sasak yang menggambarkan keyakinan masyarakat Sasak tentang masalah supranatural. Secara metodologis, penelitian ini menggunakan pendekatan hermeneutik, yakni suatu pendekatan yang berusaha menafsirkan suatu teks secara mendalam. Analisis data mengacu pada model perspektif-konstruktifis, yaitu diarahkan oleh intensi, kategori-kategori yang telah ditentukan, dan target hasil yang ingin diperoleh. Hasil penelitian ini menunjukkan bahwa di dalam cerita rakyat Sasak banyak terungkap kepercayaan kepada hal-hal supranatural, gaib, atau di luar nalar manusia. Masalah-maalah supranatural tersebut berupa karamah/keramat Wali Allah, kepercayaan terhadap kebenaran wangsit, firasat, dan mimpi, serta kepercayaan kepada makhluk halus.
\end{abstract}

Kata kunci: eksistensi, supranatural, folklor lisan, Sasak, kajian tematis. 



\section{Pendahuluan}

Kenyataan yang harus diakui adalah masih banyak kebudayaan daerah Sasak, termasuk folklor lisan yang belum diteliti sehingga belum diketahui corak atau ragamnya, apalagi nilai budaya atau nilainilai luhur yang dikandungnya. Padahal tidak bisa dipungkiri, bahwa hasil penelitian sastra lisan tentu merupakan inventarisasi kebudayaan yang sangat penting karena dengan inventarisasi itu kita akan mengetahui potensi kebudayaan yang kita miliki. Dengan mengetahui atau mengenal lebih dekat potensi kebudayaan yang dimiliki, kita tidak mudah menerima pengaruh negatif budaya luar, apalagi tercabut dari akar budaya sendiri.

Cerita rakyat Sasak (selanjutnya disingkat CRS) sebagai salah satu bagian dari folklor lisan, mengandung nilai kehidupan yang ideal. Sebagaimana halnya dengan cerita rakyat daerah lainnya, CRS banyak mengandung buah pikiran yang luhur, pandangan dunia masa lampau, pengalaman jiwa yang berharga, cerminan watak yang baik, seperti perasaan belas kasihan, anjuran untuk bekerja keras dalam hidup, dan lain-lain. Hal ini sejalan dengan pendapat Brumfit (dalam Sukatman, 1993), sastra daerah berkaitan dan memuat nilainilai masyarakat tempat sastra itu lahir.

Penelitian yang berkaitan dengan bahasa dan budaya daerah Sasak memang telah banyak dilakukan. Untuk membuktikan hal ini, peneliti perlu menyajikan beberapa di antaranya, yang untuk sementara dapat dijangkau, antara lain : Cerita Daerah Nusa Tenggara Barat (Mite dan Legenda) (Depdikbud,1981); Cerita Rakyat Daerah Nusa Tenggara Barat (Depdikbud, 1982); Peralatan Hiburan dan Kesenian Tradisional Daerah Nusa Tenggara Barat (Depdikbud, 1992), dan masih ada beberapa penelitian lainnya.

Penelitian-penelitian yang telah disebutkan di atas, khususnya yang berbentuk folklor lisan/cerita rakyat, secara umum masih bersifat penginventarisasian atau pendokumentasian. Kita bersyukur, bahwa tidak lanjut dari penelitian ini telah dilakukan. Beberapa di antaranya penelitian yang sifatnya analisis isi (content analysis), di antaranya, Analisis Tema, Amanat, dan Nilai Budaya (PPPB, 1993) dan, Citra Manusia dalam Folklore Lisan Sasak (Fakihuddin, 1998). Akan tetapi, sastra Sasak yang dianalisis dalam penelitian tersebut lebih difokuskan pada nilai-nilai budaya, citra manusia, dan nilai-nilai pendidikannya. Sedangkan gambaran unsur-unsur supranatural dalam CRS tersebut belum disinggung sama sekali. Itulah salah satu alasan pentingnya masalah ini dikaji secara saksama.

Perbedaan penelitian sebelumnya dengan penelitian yang dilakukan ini adalah tidak saja pada khususan cerita rakyat yang dijadikan sumber datanya, tetapi juga pada pengkajian secara lebih saksama persoalan supranatural dalam CRS yang belum banyak dilakukan. Dengan pengajian ini diharapkan potret/cara pandang masyarakat masa lampau terkait dengan kepercayaan kepada hal-hal gaib/kekuatan gaib dapat terungkap. Hal ini sejalan dengan fungsi folklor lisan (cerita rakyat), salah satunya, yaitu sebagai penggalang rasa kesetiakawanan di antara warga masyarakat yang memiliki cerita rakyat tersebut. Seperti diketahui, bahwa cerita rakyat itu lahir dan tumbuh berkembang bila sesuai dengan pikiran dan perasaan warga masyarakat secara kolektif, sebaliknya pikiran dan perasaan kolektif itulah yang memungkinkan terwujudnya cerita rakyat. Sifat tersebut akan lebih jelas lagi pada cerita rakyat yang bersifat mitologis, yang di dalamnya dikemukakan bahwa warga masyarakat pemilik cerita itu masih seketurunan atau memiliki nenek moyang sama itulah yang mengikat batin mereka. Oleh sebab itu, sangatlah beralasan 
jika masalah ini diangkat menjadi suatu objek dalam penelitian ini.

Bertolak dari latar belakang tersebut, masalah yang terdapat dalam penelitian ini yaitu belum ditemukan pengkajian khusus yang berkaitan dengan masalah supranatural dalam CRS, padahal masalah ini sangat penting untuk diungkap secara cermat. Dengan mengetahui berbagai unsur supranatural dalam CRS, pembaca (khususnya manusia Sasak), dapat mengaca diri pada sosok dan pandangan leluhur mereka dan dapat bercermin pada hal-hal yang penting atau berguna yang terungkap dalam CRS.

Permasalahan lain yang membuat perlunya pengungkapan, pemahaman, dan penerapan niali-nilai luhur/unsur supranatural dalam CRS, yaitu karena realitas menunjukan bahwa akhir-akhir ini sastra klasik, khususnya CRS semakin terbaikan. Hal ini disebabkan oleh derasnya pengaruh gaya hidup global yang masuk ke wilayah Sasak. Robson (1994:8) menilai, "di Indonesia yang dianggap maju adalah kebanyakan yang kebarat-baratan, sebaliknya yang berasal dari Indonesia dianggap kuno dan terbelakang."

Perlu dijelaskan bahwa dalam kegiatan studi pustaka di temukan satu penelitian kepustakaan yang berjudul Sastra Daerah Nusa Tenggara Barat; Analisis Tema, Amanat, dan Nilai Budaya (PPPB, 1993). Peneliti juga telah melakukan penelitian Analysis Content terhadap sejumlah CRS, yang berjudul Citra Manusia dan Nilai Edukatif dalam CRS: Suatu Kajian Tematis terhadap Folklore Lisan Sasak yang Telah Didokumentasikan. Pengkajian masalah supranatural dalam folklor lisan Sasak ini merupakan lanjutan dan pelengkap penelitian terdahulu seperti telah disajikan sebelumnya.

Dalam penelitian ini peneliti secara rinci mengungkap persoalan keyakinan terhadap kekuatan supranatural. Jadi penelitian tentang eksistensi masalah supranatural dalam CRS ini, bersifat melengkapi dan melanjutkan penelitian terdahulu, yaitu dokumentasi CRS dan analisis tema, amanat, dan nilai budaya serta citra manusia dan nilai edukatif dalam CRS. Adapun masalah dalam penelitian ini secara umum dapat dirumuskan sebagai berikut.

Bagaimanakah kepercayaan masyarakat Sasak di masa lampau terkait dengan masalah-masalah supranatural yang tercermin pada Teks Cerita Rakyat Sasak? Rumusan masalah ini masih terlalu umum sifatnya. Oleh karena itu, perlu dikhususkan sebagai berikut.

1) Bagaimanakah bentuk kepercayaan masyarakat Sasak di masa lampau terkait dengan masalah-masalah supranatural yang tercermin dalam CRS?

2) Sejauh mana kepercayaan terhadap masalah supranatural yang terdapat dalam CRS tersebut masih eksis di masyarakat Sasak sekarang?

Secara umum tujuan penelitian ini adalah untuk mengungkapkan secara cermat dan lengkap kepercayaan masyarakat Sasak zaman dahulu mengenai hal-hal yang bersifat supranatural yang terekam dalam teks CRS yang telah didokumentasikan. Adapun tujuan khusus yang ingin dicapai adalah untuk: (1) mendeskripsikan bentukbentuk kepercayaan masyarakat Sasak zaman dahulu terkait dengan masalah supranatural yang tercermin dalam CRS; dan (2) menjelaskan eksistensi kepercayaan masyarakat Sasak tentang hal-hal yang bersifat supranatural tersebut di masyarakat Sasak sekarang.

\section{Kerangka Teori}

Untuk menunjang analisis dan pemahaman terhadap tema yang dibahas, secara garis besar ada tiga hal yang perlu disajikan dalam kajian teori ini, yaitu (1) Kajian Tematis, (2) Masalah Supranatural, 
(3) Folklor Lisan, dan (4) Cerita Rakyat Sasak).

\subsection{Kajian Tematik}

Kata tematik berasal dari bahasa Inggris theme (n), dalam bahasa Indonesia diartikan dengan tema, pokok, dasar cerita, dan subjek (Herpinus Simanjuntak, 1997: 191). Kata tema diartikan oleh Poewadarminta (Kamus Umum Bahasa Indonesia, 1986:1040) sebagai pokok pikiran, dasar cerita yang dipercakapkan atau dipakai sebagai dasar mengarang. Berdasarkan makna kata theme (tema) di atas, kajian tematik yang dimaksudkan dalam penelitian ini adalah penyelidikan atau pengungkapan sesuatu berdasarkan tema, dasar pemikiran, pokok persoalan tertentu (yang dijadikan tema). Dalam penelitian ini persoalan yang menjadi fokus penyelidikan adalah masalah supranatural.

\subsection{Supernatural}

Dalam Kamus Oxford istilah supernatural dijelaskan pengertiannya sebagai berikut: Adjective (of $a$ manifestation or event) attributed to some force beyond scientific understanding or the laws of nature: a supernatural being unnaturally or extraordinarily great: a woman of supernatural beauty. Noun (the supernatural) manifestations or events considered to be of supernatural origin, such as ghosts. Derivatives, supernaturalism (noun); supernaturalist (noun); supernaturally (adverb), [as submodifier]: the monster was supernaturally strong (sumber

http://oxforddictionaries.com/definition/ame rican_english/supernatural).

Dalam Wikitionary dijelaskan masalah supernatural, "Etymology From Latin supernaturalis, from super ("above") + natura ("nature; that which we are born with"), from natus ("born"), perfect passive participle of nasci ("to be born") + adjective suffix -alis. Dalam bentuk adjective, supernatural (comparative more supernatural, superlative most supernatural) ; Above nature; that which is beyond or added to nature, often so considered because it is given by God or some force beyond that which humans are born with. In Roman Catholic theology, sanctifying grace is considered to be a supernatural addition to human nature. Not of the usual; not natural; altered by forces that are not understood fully if at all. Neither visieble normeasurable. Dijelaskan juga bahwa kata supernatural bersinonim dengan kata extraordinary, supranatural, unnatural Noun supernatural (plural: supernaturals) (countable), A supernatural being (uncountable) Supernatural beings and events collectively. (When used with definite article: "the supernatural". (Sumber: http://en.wiktionary.org/wiki/supernatural).

Berdasarkan pengertian secara
etimologis tersebut, masalah
supernatural/supranatural yang dimaksud
dalam penelitian ini, yaitu sesuatu yang
bersifat ajaib, gaib, sulit dinalar oleh akal
biasa, namun diyakini dan kadang terjadi
dalam kehidupan seseorang atau masyarakat.

\subsection{Folklor}

Folklor adalah kepercayaan adat istiadat suatu bangsa yang sudah ada sejak lama, yang diwariskan turun-temurun secara lisan atau tertulis (Sudjiman, 1990:31). Dijelaskan juga, bahwa folklor bisa berupa nyanyian, cerita, peribahasa, teka-teki, bahkan permainan kanak-kanak.

Penjelasan lebih rinci mengenai folklor ini diberikan oleh Dundes sebagai berikut. Kata folklor merupakan pengindonesiaan dari kata inggris folk-lore. Folklore terbentuk dari kata folk dan lore. Folk sama artinya dengan kata kolektif (collectivity). Menurut Dundes (dalam Danandjaya, 1991:1) kata folk adalah sekelompok orang yang memiliki ciri-ciri 
pengenal fisik, sosial, dan kebudayaan sehingga dapat dari kelompok-kelompok lainya. Ciri pengenal itu antara lain bisa berwujud: warna kulit yang sama, bentuk rambut yang sama, agama yang sama, Namun ciri yang terpenting menurut Dundes adalah mereka telah memiliki suatu, yakni kebudayaan yang mereka warisi turuntemurun, sedikitnya dua generasi, yang dapat mereka akui sebagai milik bersama dan terpenting juga adalah mereka sadar akan identitas kelompok mereka sendiri. Sedangkan kata lore dijelaskan oleh Dundes sebagai tradisi folk, yaitu sebagian kebudayaan, yang diwariskan secara turuntemurun secara lisan atau melalui suatu contoh yang disertai gerak isyarat atau alat pembantu pengingat (mnemonik device) (dalam Danandjaya, 1991:1-2). Berdasarkan pengertian tersebut, Danandjaya mendefinisikan folklor sebagai sebagian kebudayaan kolektif, yang tersebar diwariskan turun-temurun, secara tradisional dalam versi yang berbeda, baik dalam bentuk lisan maupun contoh yang disertai gerak isyarat atau alat pembantu pengingat (mnemonik device).

Untuk mempertegas pemahaman tentang folklor ini, ada baiknya disajikan sejarah pengembangan pengertian folklor tersebut. Shipley (1962:161), "folklor until the mid-19thc. populerantiquites comprised all those intrests and activities now denoted by the term folklore." Hingga pertengahan abad ke-19 masehi, istilah folklor maknanya lebih mengarah kepada benda-benda pusbakala yang menarik perhatian. Dalam kamus tersebut dijelaskan juga, bahwa Francis dan di Scandinavia, folklore is employed to embarance such matters as traditional house forms, textile methods and other asfect of material cultural usually assigned to anthropologi (1962:161). Berdasarkan keterangan tersebut, folklor cakupan pengertiannya meliputi: bentukbentuk bangunan atau rumah tradisional atau kuno, praktek-praktek pertanian, cara pembuatan tekstil, dan berbagai peralatan budaya lainnya yang biasanya digunakan dalam antropologi.

Di Inggris (dahulu) istilah folklor biasanya dibatasi pengerian pada "tradisi lisan atau tulisan dari suatu, masyarakat, yang biasanya disebut ungkapan-ungkapan seni tradisional" (spoken or writen traditions of a people, to traditional aesthetic expressions). Dalam pengertian ini, yang termasuk kedalam folklor yaitu "approaches antropology at many points, both in subject matter and in method." Shipley (1962:162) menjelaskan bahwa esensi dari folklor terletak pada ketradisionalannya "the essential quality of folklore is that it is traditional."

Sebelum perang dumia kedua, para sarjana antropologi Belanda membatasi folklor hanya sebagai kebudayaan petani Desa Eropa, sedangkan kebudayaan orangorang luar Eropa dianggap kebudayaan premitif. Hal ini tampaknya disebabkan adanya anggapan sejak zaman kolonial, bahwa meskipun folklor (kebudayaan petani Desa Eropa) lebih rendah dari kebudayaan kota atau bangsawan Eropa, namun dianggap lebih luhur jika dibandingkan dengan kebudayaan premitif seperti Indonesia. Pada masa itu, ilmu folklor di bagi dua, yakni volkskunde untuk menyebut ilmu folklor dan volkenkunde untuk etnologi atau antropologi (Danandjaya,1991).

Pasca perang dunia kedua, cakupan pengertian folklor semakin meluas. Menurut Abrams (1988), folklor mencakup hal-hal, seperti legenda, kepercayaan masyarakat, nyanyian, dongeng, peribahasa, teka-teki, pantun, budaya ilmiah semua, bintang, tanaman, upacara adat, tarian tradisional yang biasanya diupayakan dalam upacara tradisional. 


\subsection{Jenis-Jenis Folklor}

Menurut Abrams (seperti telah disajikan sebelumnya), folklor mencakup: Legenda, kepercayaan rakyat, nyanyian rakyat, dongeng, peribahasa, teka-teki, pantun, budaya ilmiah semua, binatang, tanaman, upacara adat, dan tarian tradisional yang biasanya digunakan dalam upacara tradisional.

Shipley (1962:162) menyebutkan, "the would seem to be no disagreement about its use to include all kids of folksong, folktales, supersititions, local legends, proverbs, riddles. Jadi menurut Shipley, tampaknya tidak terdapat ketidaksepakatan mengenai pemakaian istilah folklor, yakni termasuk di dalamnya semua jenis nyanyian rakyat, cerita rakyat, takhayul (supersititions), legenda, peribahasa, dan teka-teki.

Brunvand menggolongkan folklor ke dalam tiga kelompok besar, yaitu folklor (1) lisan (verbalfolklore), (2) sebagian lisan (partly verbalfolklore), dan (3) bukan lisan (non-verbal folklore) (dalam Danandjaya, 1991:21). Folklor lisan adalah folklor yang berbentuk murni lisan. Yang termasuk kedalam bentuk ini antara lain: (a) bahasa rakyat (folk speeck), seperti logat, julukan, pangkat tradisional, dan titel kebangsawanan; (b) ungkapan tradisional, seperti peribahasa, pepatah, dan pemeo; (c) pertanyaan tradisional, seperti teka-teki; (d) puisi rakyat, seperti pantun, gurindam, dan syair; (e) cerita prosa rakyat, seperti mite, legenda, dogeng, dan (f) nyanyian rakyat. Folklor sebagian lisan adalah folklor yang bentuknya campuran antar unsur lisan dan bukan lisan. Yang bentuk ini antara lain: kepercayaan rakyat, permainan rakyat, teater rakyat, tari rakyat, adat istiadat, upacara, dan pesta rakyat.

Sedangkan yang dimaksud folklor bukan lisan yaitu yang bentuknya bukan lisan walaupun cara pembuatannya diajarkan secara lisan. Folklor bukan lisan ini dibedakan ke dalam dua subkelompok, yakni material dan bukan material. Yang tergolong ke dalam material misalnya, arsitektur rakyat, seperti rumah asli daerah, bentuk lumbung padi, dan lain-lain; kerajinan rakyat, seperti pakaian dan perihiasan tubuh, makanan dan minuman rakyat, obat-obatan teradisional. Adapun yang tergolong bukan material antara lain: gerak isyarat tradisional (gesture); bunyi isyarat komunikasi rakyat, seperti kentongan, beduk, kul-kul, dan lain-lain.

\subsection{Cerita Rakyat}

Cerita rakyat (folktale) adalah kisahan anonim yang tidak terikat pada ruang dan waktu, yang beredar secara lisan di tengah masyarakat. Termasuk di dalamnya cerita binatang, dongeng, legenda, mitos, dan sage (Sudjiman, 1990:16). Menurut Tim Direktorat Sejarah dan Nilai Tradisional, cerita rakyat merupakan cerita yang pada dasarnya disampaikan oleh seseorang kepada orang lain secara lisan. Tokoh-tokoh dan peristiwa-peristiwa dalam cerita rakyat itu dianggap pernah terjadi pada masa lampau atau merupakan hasil rekaan, semata-mata ingin menyampaikan pesan atau amanat melalui cerita rakyat tersebut (majalah Analisis Kebudayaan, 1980:6565). Dijelaskan juga, bahwa cerita rakyat itu memiliki ciri: dituturkan secara lisan, sebagian besar dituturkan dalam bahasa daerah, merupakan pengungkapan cita suatu masyarakat yang memilikinya secara kreatif dan komunikatif. Pada umumnya tidak dikenal lagi pengarangnya atau penyusunnya (anonim), dan biasanya cerita rakyat itu tersebar luas dari mulut ke mulut, sehingga dalam proses penyebarannya mengalami perubahan atau penyimpangan dari bentuk serta isinya yang dahulu (1980:65).

Batasan yang tidak jauh berbeda dengan yang telah dikemukakan diberikan oleh Danandjaya (1991:50), cerita rakyat 
adalah bentuk penuturan cerita yang pada dasarnya tersebar secara lisan, diwariskan turun-temurun dari kalangan masyarakat pendukungnya secara tradisional. Danandjaya (menguntip pendapat Bascom) mengklasifiksikan cerita rakyat ini ke dalam tiga golongan besar, yakni mite, legenda, dan dogeng. Uraian selengkapnya mengenai masalah ini disajikan dalam subkajian pustaka klasifikasi cerita rakyat.

Vansina memasukan cerita rakyat ini ke dalam kelompok tuturan rakyat. Tuturan rakyat dijelaskan sebagai tuturan yang diturunkan dari generasi ke generasi, pada umumnya disebarkan dari generasi ke generasi, umumnya bersifat anonim, yaitu tidak diketahui individu yang menciptakannya, baik karena waktu berlangsungnya sudah lama maupun karena memang tuturan itu selama proses pemindahannya mengalami perubahan oleh tindakan penutur dan pendengarnya yang tidak terbatas sehingga tuturan itu diciptakan sepanjang proses penuturannya (dalam Rusyana, 1983:29). Dijelaskan bahwa perubahan itu terjadi, misalnya, disebabkan oleh keperluan untuk menciptakan atmosfer tertentu dan oleh reka cipta penutur yang berhasrat memperbaiki bahannya untuk memenuhi kesenangan pendengarnya.

Dari batasan-batasan dan penjelasan tersebut dapat disimpulkan, bahwa cerita rakyat adalah cerita atau tuturan yang disampaikan seseorang kepada orang lain atau dari generasi berikutnya, secara turuntemurun sebagai alat untuk menyampaikan pesan atau amanat tertentu.

\subsection{Cerita Rakyat sebagai Bagian dari Folklor Lisan}

Jika dicermati pengertian folklor dan ciri-ciri utamanya, seperti telah disajikan, tidak bisa dipungkiri lagi bahwa cerita rakyat adalah salah satu bentuk folklor lisan. Menurut Danandjaya, dari semua bentuk atau genre folklor yang paling banyak diteliti para ahli adalah cerita prosa rakyat. Menurut Rusyana (1982/1983) cerita rakyat merupakan salah satu bagian dari tuturan lisan. Tuturan lisan (tradisi lisan) ini termasuk ke dalam cakupan folklor. Penjelasan Rusyana secara lengkap disajikan sebagai berikut.

Tuturan rakyat sebagai bagian folklor
merupakan bagian tuturan yang telah
lama hidup dalam tradisi suatu
masyarakat. Tuturan rakyat itu merupakan
tuturan yang telah dituturkan kembali di
antara orang-orang yang berada di antara
beberapa generasi... Tuturan rakyat
sebagai bagian dari folklor mengandung
survival, yaitu suatu yang masih terdapat
dalam budaya masa kini sebagai
peninggalan dari masa sebelumnya
(Rusyana, 1982/1983).

\section{Metode Penelitian}

Rancangan yang digunakan dalam penelitian ini adalah kualitatif yang bersifat deskriptif-interpretatif. Hal ini karena (1) menggunakan dokumen karya sastra, yakni dokumen/teks CRS sebagai objek kajian utama, (2) data penelitian ini adalah data verbal, yaitu berupa sekuen-sekuen tertentu yang saling terkait dari teks CRS yang mengandung masalah supranatural, (3) fokus penelitian ini adalah makna sebagai nilai, (4) proses penelitian ini didasarkan pada signifikansi interpretatif, (5) peneliti sendiri sebagai instrumen kunci (human instrument), dalam hal ini sebagai interpretator, dan (6) berusaha mendeskripsikan dan menginterpretasikan makna yang dikandung CRS tersebut. Alasan ini sejalan dengan pandangan Bogdan dan Taylor (1973) yang mengatakan bahwa penelitian kualitatif adalah penelitian yang menghasilkan data desktiptif berupa kata-kata tertulis atau lisan (dibandingkan dengan Miles \& Huberman, 1984:15-16).

Dalam penelitian ini dibedakan antara pendekatan yang bersifat metodologis dan teoritis. Pendekatan (yang bersifat metodologis) yang digunakan dalam 
penelitian ini adalah hermeneutik. Pemilihan metode ini dipandang tepat karena sesuai dengan tugas pokok hermeneutik, yaitu menginterpretasikan sebuah teks sehingga dapat dimengerti oleh banyak orang pada zaman yang berbeda (adaptasi dari Hidayat, 1996). Terkait dengan masalah ini, Suryawinata menyebutkan bahwa salah satu dasar pokok penelitian sastra adalah interpretasi, yang tidak lain adalah hermeneutika (dalam Aminuddin, (ed.), 1990:144).

Data penelitian ini berupa data verbal, yaitu berupa sekuen-sekuen atau bagianbagian tertentu dari CRS yang mengadung unsur supranatural. Adapun sumber data dalam penelitian ini dibatasi pada CRS yang telah didokumentasikan; baik oleh Proyek Penerbitan dan Pencatatan Kebudayaan Daerah Departemen Pendidikan dan Kebudayaan, Proyek Penerbitan Buku Sastra Indonesia dan Daerah Jakarta; Pusat Pembinaan dan Pengembangan Bahasa Departemen Pendidikan dan Kebudayaan, Jakarta maupun oleh Proyek Penelitian dan Pencatatan Kebudayaan Daerah, Departemen Pendidikan dan Kebudayaan Mataram. Buku-buku yang dijadikan sumber data dalam penelitian ini adalah: (1) Cerita Rakyat Daerah Nusa Tenggara Barat (Depdikbud Mataram, 1978); (2) Cerita Rakyat Nusa Tenggara Barat (Mite dan Legenda) (Depdikbud Jakarta, 1981); (3) Cerita Rakyat Daerah Nusa Tenggara Barat (Depdikbud Jakarta, 1982); dan (4) Sastra Lisan Sasak (PPPB Jakarta, 1987).

Teknik pengumpulan data dalam penelitian ini adalah studi dokumentasi. Studi ini dilakukan dengan jalan membaca teks (dokumen) CRS. Pemilihan studi dokumentsi ini sesuai dengan keadaan penelitian ini, yaitu cerita rakyat Sasak yang menjadi sumber data sudah didokumentasikan oleh peneliti terdahulu. Berdasarkan dokumen cerita rakyat tersebut, peneliti mengumpulkan data terpilih melalui kegiatan membaca. Dikatakan data terpilih karena data tersebut harus mampu memberikan informasi sesuai dengan permasalahan yang diajukan peneliti. Untuk menemukan data terpilih tersebut, dilakukan kegiatan membaca secara observatif, membaca secara kritis, dan membaca secara evaluatif. Pada tahap membaca observatif, dilakukan kegiatan membaca teks CRS secara keseluruhan guna memperoleh informasi dari bacaan. Pada tahap membaca kritis, peneliti berusaha memahami kesesuaian informasi dalam bacaan dengan konteks yang diacu dan mengidentifikasikan sistem tanda dalam bacaan dengan konteks sosial budaya Sasak. Selanjutnya, untuk memahami kelayakan motif pemaparan konsep-konsep tertentu dalam bacaan dihubungkan dengan konteks sosial-budaya masyarakat pemilik cerita (Sasak). Untuk itu dilakukan wawancara dengan para budayawan atau para pengamat budaya Sasak. Hal ini dilakukan untuk memperkaya "critical judgement" peneliti. Sedangkan membaca secara evaluatif dimaksudkan untuk menilai kesepadanan gambaran nilai dalam teks dengan konsep yang ingin digarap peneliti.

Instrumen utama penelitian ini adalah peneliti sendiri (human instrument). Peneliti sebagai instrumen peneliti merupakan salah satu ciri pokok penelitian kualitatif (Bogdan dan Biklen, 1992). Dalam penelitian kualitatif, peneliti sendiri atau dengan bantuan orang lain merupakan alat pengumpul data utama (Moleong, 1995:4). Peneliti langsung sebagai instrumen kunci, ia mengarahkan semua kemampuan intelektual, pengetahuan dan keterampilan dalam mengumpulkan data, dan mencatat segala fenomena yang diamati (Semi, 1990:24). 


\section{Pembahasan}

\subsection{Bentuk-Bentuk Kepercayaan terhadap Masalah Supranatural}

Setelah dilakukan pengkajian secara cermat dan saksama, bentuk-bentuk kepercayaan masyarakat Sasak zaman dahulu tentang masalah supranatural/hal-hal yang bersifat ghaib/ajaib atau sulit dinalar oleh logika normal dapat disajikan sebagai berikut.

\subsubsection{Kepercayaan Keramat Wali Allah}

"Wali Allah" (waliyullah) berarti kekasih Allah. Bentuk jamak dari kata wali adalah "auliya". Jadi bentuk jamak dari waliyullah adalah "auliya'Allah" (Rakhmat, 1991:130). Karena wali itu kekasih Allah, maka tentu saja dia orang yang sangat dekat dengan Allah. Begitu dekatnya, sehingga ia menyerap sifat-sifat Allah sampai ke tingkat tinggi-tingginya. Karena Wali Allah tersebut dalam agama Islam disebut "karamah" (keramat dalam bahasa Sasak). Dalam keyakinan masyarakat Sasak, keistimewaan seorang Wali Allah tampak pada apa saja yang dikatakannya terbukti. Keistimewaan lain lari Wali Allah adalah kehadirannya mendatangkan berkah kepada orang-orang di sekitarnya (Rakhmat, 1991:131). Keyakinan terhadap Wali Allah ini tergambar secara jelas dalam CRS yang berjudul "Gaos Abdul Razak" (GAR) dan "Wali Nyatoq" (Wny.) pengakuan eksistensi Wali Allah secara eksplisit terungkap pada data berikut.

(1) Tersebutlah sebuah cerita yang berasal dari orang-orang tua dari Sekar Bela. Diceritakan dua orang Wali yang berasal dari Kalimantan berlayar menuju Pulau Lombok. Mereka menumpang perahu Banjar. Setiba di tengah laut, perahu diterjang badai dan gelombang yang amat dahsyat. Akhirnya perahu itu pecah dan berkeping-keping. Tiba-tiba sekeping pecahan itu berubah menjadi batu.
Dengan kepingan itulah dua Wali itu melanjutkan perjalanan menuju darat Lombok. Akhirnya mendarat di sebuah pantai. Itulah sebabnya hingga kini pantai desa sekitarnya dinamai Batu Layar (GAR, 1981:90).

(2) Sebenarnya yang masyhur dengan sebutan Wali Nyatok adalah Abdul Kadir Bagdadi. Ia berasal dari Bagdad. Setelah lama mempelajari Agama Islam di negeri itu, untuk memperdalam pengetahuan Islam ia pergi ke kota Mekah. Di sana ia menyerahkan diri sebagai murid. Ia salah seorang murid yang pandai, cerdas dan sangat rajin.... (Wny., 1981:119)

Dari kedua data tersebut (1 dan 2), tergambar bahwa sejak zaman dahulu masyarakat Sasak sudah mengakui dan meyakini Waliyullah. Cerita tentang Wali Allah yang bernama Gaos Abdul Razak dan Wali Nyatoq, bukan saja ada dalam cerita lisan (cerita rakyat yang telah didokumentasikan), tetapi hingga sekarang masih hidup di kalangan masyarakat Sasak.

Kekuatan supranatural terkait dengan kewalian ini, yaitu dalam waktu yang bersamaan masing-masing orang melihat Gaos Abdul Razak berbeda-beda. Misalnya, ada yang melihatnya sedang minum tuak, ada yang melihatnya sedang menyabung ayam, ada yang melihatnya sedang duduk di rumah penduduk, ada yang melihatnya sedang bersembahyang di sebuah masjid (yang sekarang bernama masjid Sekar Bela). Kejadian itu dapat dilihat pada kutipan berikut ini.

(3) Kemudian berangkatlah dua orang utusan untuk memenuhi perintah raja. Dari Kebon Kongoq mereka menuju Batu Ujung Pagutan. Di sana mereka melihat ulama itu sedang minum tuak (air enau yang sudah diisi ragi).... Setelah kedua utusan itu berangkat, akhirnya tiba di Desa Pegesangan. Di sini mereka melihat Gaos Abdul Razak 
sedang menyabung ayam.... Setelah itu kedua utusan menuju Kampung Seren. Di sini mereka melihat Gaos Abdul Razak sedang duduk di rumah penduduk.... Sedang dua utusan lainnya melihatnya sedang sembahyang di sebuah masjid, yang sekarang bernama masjid Sekar Bela (GAR, 1981:90-91).

Keajaiban lainnya, yaitu ketika GAR sudah dibunuh dan kepalanya dimakamkan di sebuah makam yang bernama Makam Otak-Otak. Setiap Raja Bali yang lewat dimakam itu tiba-tiba saja terjatuh. Hal ini dialammi oleh orang Hindu yang memimpin waktu itu, yaitu Gusti Ketut Gosha dan Anak Agung Ketut Jelantik. Keajaiban ini dapat dilihat pada data berikut.

(4) "Mendengar itu Gusti Ketut Gosha segera berangkat, menuju Sekar Bela. Menjelang lima belas meter akan tiba di kuburan otak-otak, tiba-tiba Gusti Ketut Gosha terjatuh. Rakyatku sekalian, telah kerap kali aku datang di tempat ini, tak pernah aku mengalami pengalaman seperti ini. Apakah kirakira sebabnya?"

Mendengar itu berangkat Anak Agung Ketut Jelantik menuju Sekar Bela. Setiba di Pegesangan, ia beristirahat sesaat, kemudian melanjutkan perjalanan menuju ke arah barat menuju Sekar Bela. Setelah berada lima belas meter dari kubur otak-otak, raja pun terjatuh bersama pengiring serta kudanya (GAR:92).

Masih banyak keajaiban lain yang diyakini sebagai keramat wali (GAR) yaitu munculnya sebuah mata air dengan ledakan yang dahsyat, ketika rakyat Sekar Bela baru tujuh hari dipindahkan ke Punia. Mata air ini berpindah lagi ke Sekar Bela setelah raja (Ketut Jelantik) berniat mendirikan istana raja di sekitar mata air. Pindahnya mata air ini berhubungan dengan pindahnya murid
Gaos ke Sekar Bela atas perintah raja. Keanehan seperti dijelaskan tersebut dilihat pada data berikut.

(5) Setelah mereka berada tujuh hari di Punia, tiba-tiba muncul keajaiban. Mata air muncul dengan ledakan yang dahsyat.... "Nah telah lama kau tinggal di tempat ini. Sekarang aku berniat membangun istana. Sedang kamu akan kukembalikan ke Sekar Bela. Perbesarlah kampungmu di sana.... Setelah seminggu mereka membuat perumahan baru, muncul lagi sebuah mata air dengan ledakan dahsyat seperti yang terjadi di Punia. Bersamaan dengan itu mata air yang di Punia tibatiba menjadi kering. Melihat keadaan itu Gusti Ketut Gosha menghadap kepada Anak Agung dan memberi laporan (GAR:94-95).

Banyak lagi keanehan dan keajaiban berkat keramat Wali Allah tersebut. Keanehan seperti ketika kubur otak-otak itu digali untuk dipindahkan yang ditemukan adalah sebatang anak pohon pisang. Padahal dahulu yang dikuburkan oleh muridmuridnya adalah kepala Gaos Abdul Razak (GAR, hlm.95). Turunnya hujan lebat disertai angin ribut, guruh, dan kilat serta gelombang laut yang amat besar, ketika rombongan Gusti Ketut Gosha (sebanyak 1740) berziarah ke makam Loang Balok (makan tempat dipindahkannya kubur otakotak) (hlm.98). keajaiban lain adalah munculnya di tengah laut bayangan Gaos Abdul Razak, yang sedang menunggang kuda dan terdengarnya sebuah suara (hlm.99); dan berbagai keajaiban lainnya.

(6) Tatkala hal demikian itu diketahui oleh Wali Nyatoq, ia berkesimpulan bahwa Datu Sakra sudah bertindak kurang baik. Wali Nayatoq tidak bisa menerima tindakan tersebut. Dengan segera ia meninggalkan selamatan itu. Ditinggalkan Desa Mendung dan menuju Desa Pejanggiq jauh di sebelah 
barat. Hal itu segera diketahui Datu Sakra. Oleh karena itu, ia segera memerintahkan patihnya untuk menyusul Wali Nayatoq.... Diceritakan kini sang patih yang sedang menyusul perjalanan Wali Nayatoq. Dalam perjalanan ini sang patih melarikan kudanya sekencang-kencangnya. Sedang Wali Nyatoq berjalan biasa. Walaupun demikian sang patih tak dapat menyusul Wali Nyatoq ...(Wny.,1981:121).

Keyakinan sang patih akan kewalian Wali Nyatoq semakin kuat ketika ia melihat Wali Nyatoq masuk mesjid dan seketika itu juga ia mencarinya di dalam mesjid, tetapi ia tidak menjumpai seorang pun.

(7) "Tapi jelas sekali ia masuk ke dalam mesjid ini," kata sang patih. "Saya harus mencarinya ke dalam."

"Silahkan, tuanku boleh mencarinya, tetapi tak mungkin akan menemukannya."

Maka masuklah sang patih ke dalam mesjid itu. Tak seorang pun dijumpainya.

"O, bila demikian, memang benar dia adalah seorang wali yang nyata" (Wny.:122).

Keajaiban lain yang dimiliki sebagai berkat keramat Wali Nyatoq yaitu ia mengubah dirinya menjadi seorang anak kecil yang rupanya persis seperti anak pemilik kerbau. Pengubahan diri ini dilakukan dengan maksud agar seorang bapak, menyadari keadaan anaknya yang ditinggalkan sendiri dalam keadaan tertidur. Dengan penyamaran ini, bapak (pemilik kerbau) menjadi khawatir, jangan-jangan anaknya diinjak oleh kerbau. Keajaiban seperti dijelaskan tersebut tergambar pada kutipan berikut.

(8) Adapun Wali nyatoq, dari Pejanggiq terus menuju ke Desa Rembitan di sebelah selatan. Orang pertama dijumpai di Rembitan adalah seorang bapak yang mempunyai beberapa ekor kerbau dan seorang anak kecil. Sebenarnya anak ini sudah pandai berjalan, namun masih juga ditidurkan di atas sebuah buaian. Kakinya diberi gelang. Pada waktu di tinggalkan ayahnya, anak ini sedang tidur dengan pulasnya.

Sesampai di tempat itu Wali Nyatoq mengubah diri menjadi seorang anak kecil yang rupanya tepat seperti anak yang sedang tidur itu. Ia berjalan di sekitar tempat kerbau-kerbau yang sedang beristirahat. Perbuatan semacam itu menimbulkan kekehawatiran kepada bapak tadi. Ia khawatir kalau anaknya diinjak oleh kerbau. Demikian kata hati sang bapak. Tetapi ia menjadi sangat heran dan takjub setelah mengetahui bahwa anaknya masih tidur di tempatnya (Wny:122).

Setelah Wali Nyatoq diambil dan dijadikan anak angkat oleh si pemilik kerbau, kehidupan mereka menjadi lebih baik. Kerbaunya berkembang biak dengan baik dan tidak pernah dicuri orang. Keadaan ini diyakini sebagai keistimewaan karena anak angkatnya (Wali Nyatoq) tinggal di rumahnya. Petikan kutipan berikut.

(9) Karena itu, Wali Nyatoq diambil dan dijadikan anak angkat.... Sejak itu kehidupan keluarganya menjadi lebih baik. Kerbau piaraannya tak pernah berkurang, dan berkembang biak dengan sempurna. Lagi pula tak pernah dicuri orang. Demikian kelebihan dan keistimewaan yang dialami, semenjak Wali Nyatoq berada di rumahnya (WNy.:122).

Keistimewaan Wali Nyatoq tak berhenti sampai disitu. Ketika ia beranjak dewasa, keadaan keluarga pemilik kerbau semakin bahagia. Semua keinginannya terpenuhi dengan segera. Asal ia menginginkan sesuatu, walaupun belum 
diutarakannya, sebentar saja Wali Nyatoq sudah datang membawakannya.

(10) Beberapa tahun kemudian Wali Nyatoq beranjak dewasa. Keadaan rumah tangga sang bapak semakin meningkat bahagia. Segala keinginan bapak angkatnya terpenuhi dengan segera. Entah dimana dan bagaimana cara memperolehnya tak seorangpun yang tahu. Asal bapaknya menginginkan sesuatu, walau belum dikemukakan, sebentar saja Wali Nyatoq telah datang membawakannya.... (WNy.:122).

Masih banyak lagi keajaiban yang ditunjukkan Wali Nyatoq. Misalnya peristiwa yang sangat sulit diterima akal sehat adalah ketika Wali Nyatoq ingin bersembahyang Jumat di Mekah sambil membawa bapak angkatnya, Wali Nyatoq dalam sekejap telah tiba di Mekah.

Berbagai kejadian aneh/ajaib seperti telah dipaparkan, diyakini oleh manusia dalam cerita Sasak sebagai suatu keisimewaan Wali Allah, yang dalam istilah Sasak disebut "Keramat Wali."

\subsubsection{Bertapa untuk Mendapatkan Kesaktian}

Bertapa atau dalam istilah Sasak tapah adalah menjalani olah batin dengan mengasingkan diri dengan keramaian dunia serta menahan hawa nafsu, menahan rasa lapar, rasa haus, dan rasa kantuk serta menahan nafsu lain yang bersifat biologis agar dapat mencapai ketenangan batin dan hening yang menunjang tercapainya pernyataan rasa dan cipta sehingga sampai ke tingkat kepasrahan kepada Tuhan Yang Mahakuasa guna ajaran secara gaib sesuai dengan tujuan spiritual yang ingin dicapainya (KBBI, 1995:1009).

Bagi masyarakat Sasak, bertapa atau tapah ini dilakukan di kuburan, di tempattempat sepi yang jauh dari keramaian, seperti di gunung-gunung, dan sebagainya. Bertapa dilakukan dengan tujuan-tujuan tertentu. Ada yang bertapa untuk mencari kekebalan atau ilmu kadigjayaan; ada yang ingin menjadi pemimpin (raja); dan ada juga yang bertapa untuk mendapatkan bendabenda sakti, seperti keris, pisau, dan bendabenda lainnya. Untuk mengetahui kegiatan bertapa dan tujuan-tujuannya yang diungkapkan dalam CRS, terlebih dahulu disajikan data-data berikut ini.

(11) Sesudah Raden Nuna Putra Janjaq naik tahta, memerintah dikerajaan Taun, ayahandanya yang sudah tua itu pergi bertapa ke sebuah gunung yang tinggi, diiringi putri baginda yaitu Dewi Rinjani. Konon dipuncak gunung itulah baginda tinggal berdua dengan putri baginda Dewi Rinjani. Di sana Dewi Rinjani diangkat oleh para jin menjadi kepala semua putri jin. Sejak itu pulalah konon, gunung yang tinggi di pulau Lombok, tempat mereka bertapa dan tinggal itu disebut dengan nama Gunung Rinjani (DR, 1978:23).

(12) Kini diceritakan bahwa raja Berenga bermaksud akan bertapa di Lengkoq Inan Ratu. Sebelumnya diperintahkan berapa orang petugas membersihkan pertapaan itu serta menyiapkan keperluan untk bertapa, seperti empokempok meniq siong (beras yang di gongseng sampai mekar) dan kemenyan. Setelah bertapa selama dua minggu, ia berkata kepada patih pengawalnya.

"Wahai Paman Patih! Mengapa hingga saat ini keadaan sepi-sepi saja? Petunjuk dari yang Mahakuasa belum juga datang. Apakah yang menyebabkannya?"

"Patih yang ditanya lalu menjawab, "Rupanya perlu ditambah kemenyan."

Kemenyan ditambahkan.

Setelah itu dan setelah bertapa selama satu bulan, datanglah petunjuk dari Yang Mahakuasa. 
Wahai Paman Patih. Dalam tapaku datanglah petunjuk dari Yang Mahakuasa tentang permintaanku meminta Gunamong (suatu ilmu yang menyebabkan yang empunya selalu dikabulkan kehendaknya dengan seketika)...." (DB,1978:58).

(13) .... Dan bertanyalah Doyan Mangan. "Mata apakah yang mendelik itu? Apakah kau ini jin atau manusia." Dan menjawablah yang berada dalam pohon beringin itu.

"Aku ini manusia. Aku sedang bertapa agar dapat menjadi raja di Pulao Lombok ini" (DM,1978:32).

(14) .... Tak berapa jauh mereka berjalan, kembali Doyan Mangan melihat sorot sepasang mata. Tubuh mata tersebut dibelit oleh rotan, sehingga tak dapat melepaskan diri. Demikian juga manusia berkeinginan menjadi raja, karena itu ia bertapa. Oleh Doyan Mangan diputuskannyalah rotan yang membelit itu. Kemudian ditanya siapa namanya. "O, aku bernama Sigar Penyalin" (DM:32).

Mencermati data-data di atas (1114), tergambar bahwa manusia Sasak (zaman dahulu) suka bertapa. Berdasarkan data tersebut diketahui bahwa mereka bertapa di gunung-gunung, di hutan-hutan, dan di pohon-pohon kayu besar. Bahkan ada juga yang bertapa di rumpun rotan (yang berada di tengah hutan). Berbagai tujuan mereka melakukan pertapaan, misalnya banyak untuk menghabiskan hari tua dan mencari ketenangan batin; ada yang meminta gunamong, yaitu sejenis ilmu yang membuat si empunya ilmu tersebut selalu dikabulkan kehendaknya; ada yang bertapa karena ingin menjadi raja. Dari data di atas, juga diketahui bahwa di dalam bertapa, seseorang melakukan persiapan khusus, seperti membersihkan tempat pertapaan, empok-empok beras siong, dan kemenyan.
Terlepas dari tempat mereka bertapa, bahan yang dipersiapkan, dan tujuan yang diinginkan dalam bertapa, semua yang di ungkapkan pada data di atas dan analisis di atas menggambarkan bahwa manusia Sasak suka bertapa. Bertapa ini hingga sekarang masih dilakukan oleh sebagian kecil masyarakat Sasak. Tujuan mereka bertapa tidak lagi sebatas apa yang diungkapkan dalam CRS, tetapi semakin meluas, yaitu kekebalan, kesaktian, kekayaan, pengaruh, prestise, dan sebagainya.

\subsubsection{Memercayai Ahli Nujum, Wangsit, Firasat, dan Mimpi}

Berikut disajikan secara berturut-turut unsur-unsur supranatural terkait dengan kepercayaan manusia Sasak (dalam CRS) mengenai ahli nujum, Wangsit, firasat, dan isyarat mimpi.

\subsubsection{Kepercayaan terhadap Ahli Nujum (Paranormal)}

Sebelum dianalisis kepercayaan manusia Sasak kepada ahli nujum (paranormal), terlebih dahulu perlu dijelaskan arti dari kata "nujum" tersebut. Dalam Kamus Besar Bahasa Indonesia, kata nujum diartikan dengan (n) perbintangan untuk meramalkan (mengetahui) nasib orang, dan sebagainya; orang yang mengetahui segala alam; bintang-bintang (1995:694). Dari bentuk nujum, lahir kata "menujumkan" yang berarti meramalkan. Dalam penelitian ini, nujum disamakan dengan ramalan. Oleh karena itu, "ahli nujum" disamakan dengan "peramal" (paranormal). Selanjutnya yang dimaksud percaya kepada ahli nujum (dalam penelitian ini) maksudnya mempercayai dan meyakini petunjuk-petunjuk, hasil-hasil ramalan para peramal atau paranormal.

Nujum (ramalan) adalah usaha untuk memperoleh informasi mengenai (hal-hal yang luput dari pengamatan biasa, dengan meminta bantuan pada informal yang bukan 
manusia (Dhavamony, 1995:61). Dijelaskan pula bahwa ramalan secara luas sudah diperaktikan dalam semua kebudayaan manusia dan segala zaman, khususnya di antara kaum primitif.

Ada tiga teknik yang biasa digunakan para pelaku ramalan (peramal), yaitu: (1) cara-cara ramalan mekanis, yang mengunakan manipulasi dari objek-objek material belaka dan operasinya harus disebut "kebetulan"; (2) ada ramalan lewat nujum, yaitu biasa diartikan sebagai menjalani, dengan kondisi-kondisi yang disiapkan secara istimewa, tingkah laku atau aspek tertentu dari binatang; dan (3) ramalan dengan menunjuk pada daya-daya spritual, atau kekuatan-kekuatan dengan sifat setengah manusia, adakalanya diperantarai lewat teknik dari roh pengantara (Dhavamony,1995:61). Berdasarkan pendapat Davamony di atas, peramalan dapat dibedakan menjadi tiga macam, yaitu ramalan mekanis, ritual, dan emotif.

Kepercayaan manusia Sasak terhadap ahli nujum (peramal) dan keyakinan mereka mengenai kebenaran isi ramalan, baik secara eksplisit maupun implisit, banyak ditemukan di dalam CRS. Untuk memperoleh gambaran mengenai hal tersebut, perlu data-data berikut.

(15) Dewi Mas Ari kencana menderita sakit.

Bermacam-macam dukun telah mengobatinya, tetapi ia tidak sembuh juga. Kemudian ditanyakan sebabmusabbab penyakit itu kepada seseorang tukang ramal. Tukang ramal itu menjelaskan, penyakit Dewi Mas Ari kencana hanya bisa disembuhkan apabila diobati dengan pok jengi (mangga jenggi). Sedangkan pok jenggi itu hanya ada di lautan selatan (BM,1978:43).

(16) "Hai semua ahli nujum maupun ahli palak, cobalah kalian tunjukan sekarang tempat tinggal yang harus kubanggakan. Di mana aku dan semua rakyatku harus menetap. Tunjukan tempat itu hingga aku dan rakyatku dapat mencapai kebahagiaan lahir batin."

Setelah berpikir beberapa lama, maka para ahli nujum dan ahli palak telah mencapai kata sepakat.

“...Pangeran junjungan kami, bila tekad telah bulat di hati pangeran untuk mencari tempat membangun desa baru, menurut kami semua, arah yang harus Tuanku telusuri adalah arah barat daya...." (DL,1981:28).

(17) "Karena firasat itu selalu mengganggu dirinya, ia pun memanggil seluruh ahli nujum yang berada di kerajaan itu. Mereka diminta meramalkan tanda ajaib yang dimiliki putranya (ABG,1982:91).

Data-data tersebut $\quad(15-17)$ mengunggkapkan secara eksplisit, bahwa manusia Sasak sejak dahulu memercayai ahli nujum (paranormal). Pada data (15), digambarkan bahwa paranormal digunakan sebagai petunjuk obat yang dapat menyembuhkan penyakit Dewi Mas Ari Kencan. Pada data (16) dilukiskan betapa pentingnya para ahli nujum dalam menentukan (memberikan) informasi, mengenai tempat yang paling baik untuk mendirikan perkampungan baru, yang kelak bisa memberikan kebahagiaan bagi raja dan rakyatnya. Sedangkan pada data (17) para ahli nujum diminta oleh Sang Raja (Datu Mas Pati) untuk memecahkan suatu misteri, yaitu suatu tanda yang amat aneh (ujung kemaluan putranya yang baru lahir) kerap bercahaya memancarkan sinar. Para ahli nujum diminta meramalkan makna dari tanda ajaib yang dimiliki putranya itu.

Lebih jauh lagi keyakinan kepada para ahli nujum dan hasil peramalannya, memperkuat anggapan peneliti bahwa manusia Sasak sangat percaya kepada paranormal. Hasil peramalan ahli nujum, seperti penyakit Dewi Mas Ari Kencana 
(Permaisuri Raja Selaparang), hanya bisa diobati dengan pok jenggiq (data 15), oleh tokoh diyakini benar. Sebab setelah makan Pok Jenggiq itu, permaisuri raja bisa sembuh. Hal ini tampak pada kutipan berikut.

(18) Setelah berada di lautan selatan, tampak olehnya sebiji Pok Jenggiq dan disambarnyalah mangga itu, kemudian dipersembahkan kepadanya Dewi Mas Ari Kencana. Setelah itu Dewi Mas Ari Kencana sembuh...." (DM, 1978:43-44)

Begitu juga dengan ramalan tentang tempat yang baik untuk dijadikan sebuah perkampungan (oleh Raden Mas Panji Tilar Negara) juga diyakini kebenarannya. Sebab tempat yang ditunjukkan oleh ahli nujum tersebut, di kemudian hari berubah menjadi sebuah kerajaan yang dikenal dengan Kerajaan Langko. Kerajaan Langko menjadi tempat yang aman, damai, sentosa lahir batin. Hal ini terbukti dari kutipan berikut, "Setelah berjalan beberapa tahun, Desa Langko telah berubah menjadi Kerajaan Langko. Rakyat hidup dalam keadaan aman, damai, serta sentosa, bahagia lahir-batin" (DL, 1981:33).

Adapun kebenaran ramalan para ahli nujum tentang misteri ujung kemaluan putra raja (Datu Mas Pati), juga terbukti kebenarannya. Kesepakatan para ahli nujum yang memberi makna bahwa keanehan pada ujung kemaluan putra raja itu bermakna suatu tanda panas, memang terbukti. Hal ini tergambar dari perjalanan hidup putra raja (Arya Banjar Getas), seperti ketika remaja, ia dituduh menodai permaisuri raja (orang tua angkatnya), dan masalah ini membuatnya harus meninggalkan istana. Begitu juga dalam keseluruhan perjalanan hidupnya, ia selalu berhadapan dengan berbagai bahaya atau selalu direncanakan untuk dibunuh oleh raja yang sedang berkuasa.

\subsubsection{Wangsit, Firasat dan Mimpi}

Kecuali mempercayai ahli nujum (paranormal). Manusia Sasak juga mempercayai adanya pesan-pesan atau amanat gaib (wangsit), firasat, dan mimpi. Gambaran mengenai kepercayaan manusia Sasak terhadap hal-hal tersebut disajikan berturut-turut sebagai berikut.

\subsection{Wangsit}

Sebagaimana telah disebutkan, manusia dalam CRS mempercayai wangsit atau adanya pesan-pesan gaib. Hal ini tergambar dari pengakuan para tokoh cerita. Banyak pesan gaib yang harus diikuti atau diamalkan oleh tokoh cerita. Pesan-pesan gaib tersebut kadang-kadang berupa petunjuk untuk melakukan suatu pekerjaan. Gambaran yang lengkap mengenai wangsit ini dapat dilihat pada data-data berikut.

(19) Dalam pertempuran babak kedua inilah Datu Taun dapat menangkap Raden Nuna Putra Janjaq. Akan tetapi, ketika akan diangkat untuk menghempaskan dan dilempar ke luar istana, suara gaib terdengar memberitahukan bahwa yang dilawan bertenpur itu adalah putranya sendiri. Suara gaib itu berbunyi demikian:

"Hai Datu Taun, jangan kamu aniaya anak itu, karena ia adalah anakmu yang sejati dari istanamu Dewi Mas." Setelah menerima pemberitahuan dari suara gaib itu, dilepasnyalah Raden Nuna Putra Janjaq dengan seketika. Lalu dirangkul dan dipeluknya dengan mesra sekali disertai penyesalan dan kesedihan mendalam di hatinya (DR, 1978:22)

(20) "Nah sekarang cobalah ceritakan selawat dan serakal bersama-sama. Kemudian darah itu dapat dimasukkan ke liang lahat." Setelah selesai membacakan selawat dan serakal, terdengarlah suara gaib. "Kerjakanlah baik-baik perigi makam itu murid- 
muridku. Hiduplah kamu dengan rukun. Jangan sekali-kali bercekcok atau membuat persoalan. Kalian yang empat puluh empat sejak sejak di dunia ini hingga di akhirat. Kita akan berjumpa di padang mahsyar" (GAZ, 1981:99-100).

(21) Rombongan tiba di makam Padang Reaq, pada saat menjelang tengah hari. Tiba-tiba terdengar kembali suara gaib: "Nah, murid-muridku, kamu memang orang-orang baik. Kamu telah melakukan perintahku. telah mendatangi tempat ini. Semoga Tuhan memperpanjang usiamu dan semoga negeri ini selalu aman dan sentosa, serta tak ada orang yang berniat meruntuhkan kerajaan ini. Sampaikan juga pesanku kepada Anak Agung, agar kalian tetap dilindungi selama hidupmu selama akhir hayat" (GAZ, 1981:101).

Kutipan-kutipan cerita $(19,20,21)$ menggambarkan bahwa manusia Sasak meyakini hal gaib tentang adanya wangsit atau pesan-pesan gaib. Pada data (89) pesan gaib hadir ketika Datu Taun sedang bertarung dengan putranya sendiri (yang selamanya ini tidak diketahuinya). Ketika Datu Taun ingin melemparkan musuhnya ke luar istana, suara gaib terdengar. Mencermati saat suara gaib itu muncul dan pesan yang disampaikan, tampak bahwa pesan gaib berfungsi sebagai penyelamat putra Datu Taun dan menyatukan kembali keluarga Datu Taun yang telah bercerai selama puluhan tahun, akibat fitnahan permaisuri kedua Datu Taun.

Sedangkan pada data (20), pesan gaib muncul ketika empat puluh empat murid setia Gaos Abdul Razak melihat sesendok darah di tumpukan daun jagung. Mereka ingin mengambil darah itu (karena mereka yakin itu darah guru mereka), tetapi tidak seorangpun yang mampu memegangnya. Darah tersebut selalu bergerak ketika diambil. Keanehan itu membuat mereka sepakat untuk membacakan selawat dan serakal (serakal $=$ membaca kitab Barzandji). Setelah membaca selawat dan serakal itu, muncullah suara gaib. Adapun pada data (21) pesan gaib muncul ketika empat puluh empat murid Gaos Abdul Razak tiba di makan Pada Reaq (dalam rangka ziarah kubur). Isi pesan gaib pada saat itu adalah pujian guru terhadap muridnya, doanya kepada Tuhan, agar murid-muridnya diberi usia panjang, dan amanat Gaos buat penguasa pada saat itu.

Berdasarkan analisis tersebut, dapat dikatakan bahwa manusia Sasak mempercayai adanya wangsit (suara gaib, pesan gaib); bahkan tidak sekedar percaya, tetapi menjalankan isi pesan/amanat tersebut. Kepercayaan yang kuat terhadap wangsit dan kesetiaan untuk melaksanakannya, hingga kini masih ditemui pada sebagaian kecil masyarakat Sasak, terutama mereka yang berprofesi sebagai dukun, tukang tenung, dan sebagainya.

\subsection{Firasat}

Di dalam Kamus Bahasa Indonesia (1995:277) ditemukan beberapa makna kata "firasat", yaitu: (1) keadaan yang dirasakan (diketahui) akan terjadi sesudah melihat gelagat, (2) kecakapan untuk mengetahui (meramalkan) sesuatu dengan melihat keadaan (muka, urat tangan, dan sebagainya), (3) pengetahuan tentang tandatanda pada badan untuk mengetahui tabiat (untung-malang) seseorang, dan (4) keadaan muka (mata, bibir dan sebagainya) yang dihubung-hubungkan dengan tabiat orangnya.

Dari keempat makna firasat, dapat disimpulkan bahwa firasat berkaitan dengan perasaan seseorang tentang sesuatu yang akan terjadi; kecakapan seseorang untuk mengetahui (meramalkan) sesuatu dengan melihat tanda-tanda fisik; dan pengetahuan tentang tanda-tanda yang ada pada fisik 
seseorang dikaitkan dengan nasib (baikburuk) yang akan menimpanya.

Selain kepercayaan kepada wangsit, sebagaimana telah dipaparkan sebelumnya, keyakinan tentang kebenaran suatu firasat banyak juga mewarnai kehidupan manusia Sasak. Hal ini terungkap dalam CRS. Untuk membuktikan masalah ini, perlu disajikan data-data sebagai berikut.

(22) Lama kelamaan... setelah sekian lama warga Titiq Cekor mendiami Desa Lendang Bila, Sempak, dan Desa Penasan, Titiq Cekor menerima suatu firasat bahwa ia akan dikunjungi oleh Batara Sang Upati (Nenek moyang para Brahmana di Bali dan di Lombok). Oleh karena itu, Titiq Cekor cepat mengumpulkan pemuka masyarakat, yang berupa Toaq-lokaq serta anak cucunya sekalian (BB,1978:82).

(23) Anak cucuku, kusuruh memukul kentongan untuk memangil kalian karena aku menerima firasat di dalam mimpi, bahwa kita akan dikunjungi Batara Sang Upati.... pada bulan purnama kuajak engkau bersama-sama turun dari gunung ini menuju ke pantai Sorongan Jukung. Karena menurut firasatku Batara Sang Upati akan tiba saat bulan purnama ini.... (BB, 1978:82).

(24) Singkat cerita hari menjelang pagi. Fajar kemerahan telah membentang di upuk timur. Burung itu juga segera bangun dan terbang menuju arah barat. Tak berapa lama dia berada di benua Afrika. Burung itu hinggap di batang pohon. Dengan segera Haji Ali Batu melepaskan ikatannya dan berpegang pada cabang pohon. Di saat itu timbullah firasat pada pikiran Ali Batu, bahwa burung itu sebenarnya penjelmaan malaikat, yang sengaja datang untuk menolong dirinya...." (HAB, 1981:56).
(25) Tentang hal itu Gaos Abdul Razak merasakan suatu firasat, tetapi ia tetap diam. Setelah kelompok orang-orang itu berkumpul, maka Gaos Abdul Razak dipanggil oleh seorang murudnya yang paling utama. Ketika ia memenuhi panggilan itu, tiba-tiba ia disergap, kemudian di ikat,akhirnya dibunuh (GAZ,1981:91).

Sejak lahir putra itu memiliki suatu tanda yang amat aneh. Ujung kemaluannya kerap bercahaya memancarkan sinar. Melihat itu Datu Mas Pati menjadi gelisah. Ia memandang hal itu sebagai suatu firasat kurang baik (ABG,1982)

Data-data yang telah dikutip (22-25) mengambarkan tokoh utama cerita mengenai firasat dan kebenarannya. Secara tidak langsung hal ini melukiskan bahwa manusia Sasak menyakini kebenaran suatu firasat. Pada data (22) diungkapkan firasat hadir lewat sebuah mimpi. Pada data (23), firasat tokoh utama cerita (HAB) muncul setelah melihat keadaan (keanehan) dari burung besar yang baru saja membawanya terbang. Firasatnya mengatakan, burung itu adalah seorang malaikat yang sengaja diutus Allah untuk menolongnya. Kesimpulan semacam itu muncul setelah melihat gelagat aneh dari burung itu, yakni lenyap seketika, entah kemana. Sedangkan pada data (24) digambarkan adanya firasat yang mendahului suatu peristiwa, tanpa dikaitkan dengan keadaan fisik atau tanda-tanda aneh pada badan seseorang. Firasat semacam itu diketahui dan dirasakan secara halus, berupa bisikan batin. Firasat ini dialami (GAR) sebelum ia mati dibunuh murid-muridnya. Ketika ada rencana pembunuhannya oleh Anak Agung Wirawangsa (raja yang memerintah dikebun buruk, tetapi ia diam saja).

Adapun pada data (25) digambarkan firasat dikatakan dengan tanda-tanda pada anggota badan, yaitu tanda aneh pada ujung 
kemaluan Arya Banjar Getas. Kelainan tersebut diyakini sebagai firasat kurang baik, yang dalam CRS (Arya Banjar Getas) disebut sebagai suatu tanda panas. Tanda panas (dalam keyakinan masyarakat Sasak), berarti akan menimbulkan bencana di kemudian hari.

Berdasarkan analisis tersebut, dapat dikatakan bahwa manusia Sasak mempercayai dan menyakini firasat; baik yang berkaitan yang melihat tanda-tanda pada badan seseorang maupun tanpa di dahului keanehan-keanehan/kelainan pada fisik seseorang.

\subsection{Mimpi}

Manusia Sasak tidak hanya menganggap mimpi sebagai sesuatu yang terlihat atau dialami waktu tidur (bunga tidur semata), tetapi diyakini sebagai suatu isyarat atau pemberitahuan dari Tuhan. Kecuali itu, mimpi diyakini sebagi suatu firasat tentang terjadinya sesuatu. Apa pun bentuknya, mimpi bagi manusia Sasak diyakini sebagai sesuatu yang bermakna. Keyakinan tentang mimpi yang telah disebutkan, tampak pada data-data berikut.

(26) Sementara itu tersebutlah sebuah kisah di pulau Jawa. Pada suatu malam permaisuri bermimpi sedang mengail di tengah laut. Pada saat itu ia memperoleh sebuah permata yang sangat bagus, bercahaya dan bergemelapan. Ketika terjaga, permaisuri itu pun mengerti selukbeluk mimpi, Sang raja menafsirkan bahwa mimpi itu bukanlah kembang tidur semata, tetapi merupakan isyarat baik dari Tuhan Yang Mahakuasa. Karena itu, Sang raja segera memerintahkan para pembesar negeri akan turut serta mengail di tengah laut yang disebut di dalam mimpi permaisuri (ABG,1982:92).

(27) Pada saat tengah malam, Banjar Getas pun menerima perintah dalam mimpi.
Perintah itu mendesak agar Banjar Getas kembali ke Pejanggiq, karena akan terjadi suatu musibah (ABG,1982:100).

(28) "Anak cucuku, kusuruh memukul kentongan unuk memanggil kalian karena aku menerima firasat dalam mimpi, bahwa kita akan dikunjungi oleh Batara Sang Upati. Nah itulah sebabnya kau kupanggil...." (BB,1978 8:82-83).

Jika data-data $(26,27,28)$ dicermati, tampak bahwa manusia Sasak tidak hanya menganggap mimpi sekedar sebagai bunga tidur semata, tetapi mimpi diyakini sebagai suatu isyarat, petunjuk atau pemberitahuan Tuhan tentang sesuatu yang akan terjadi; baik tentang sesuatu yang menguntungkan maupun yang merugikan. Mimpi sebagai sesuatu pertanda baik dari Tuhan Yang Mahakuasa dilukiskan pada data (26). Peristiwa yang hadir dalam mimpi diyakini sebagai suatu perintah (data 27); dan mimpi dimaknai sebagai suatu firasat, bahwa yang bermimpi akan didatangi seseorang (digambarkan pada data (28).

Berdasarkan analisis data $(26,27,28)$, tampak bahwa mimpi bagi manusia Sasak bukanlah sekedar sesuatu yang dialami waktu tidur yang tanpa makna, akan tetapi mimpi, adalah sesuatu yang bermakna (isyarat, petunjuk, firasat, dan sebagainya).

\subsubsection{Mahluk Halus}

Mahluk halus adalah mahluk yang dianggap hidup di alam gaib atau yang berada di luar alam fisik, misalnya jin, setan (iblis), dan sebagainya. Kepercayaan kepada mahluk halus (dalam penelitian ini), yaitu kepercayaan terhadap adanya mahlukmahluk yang hidup di alam gaib atau yang berada di luar alam fisik. Anaisis berikut ini difokuskan pada mahluk halus yang bernama "Jin" dan mahluk rohaniah yang bernama "malaikat." 
Sebelum dianalisis bagaimana kepercayaan tokoh cerita, terlebih dahulu perlu disajikan tulisan terdahulu tentang kepercayaan masyarakat Sasak mengenai mahluk halus ini. Dalam buku Adat Istiadat Daerah NTB (1977/1978) yang diterbitkan proyek Penelitian dan Pencatatan Kebudayaan Daerah Departemen Pendidikan dan Kebudayaan, dijelaskan sebagai berikut.

(29) Hampir semua suku bangsa yang mendiami Nusa Tenggara Barat, masih mempercayai adanya mahluk halus. Mahluk halus tersebut diyakini dapat mengganggunya. Di Lombok ada mahluk halus yang disebut bakeq dan jin (jin). Baiq bakeq maupun jin keduanya bertempat tinggal di bagian alam yang dianggap angker, di pohon kayu besar, gunung, bahkan di dekat kampung pun ada bakeq dan jinnya....

Di Lombok selain bakeq dan jin, masih dipercayai adanya mahluk halus lain yang menakutkan dan mengganggu manusia, yaitu bebei dan bebodo. Adalah jin perempuan yang suka menyembunyikan anak kecil pada waktu maghrib. Dari penjelasan ini, tampak bahwa masyarakat Sasak sejak dahulu telah mempercayai atau mengakui adanya berbagai mahluk halus, seperti bakeq jin, bebei, dan bebodo. Dalam analisis berikut, disajikan kepercayaan manusia Sasak terhadap mahluk halus yang bernama jin (jin). Diyakini bahwa mahluk halus yang bernama jin ini, terbagi atas dua macam, yaitu jin kafir dan jin Islam. Jin sebagaimana manusia, ada yang baik ada pula yang jahat; ada yang suka menolong manusia, ada pula yang suka mengganggu dan mencelakakan manusia.

Dalam CRS diungkapkan bahwa manusia Sasak tidak saja mengakui adanya mahluk halus yang bernama jin, tetapi diyakini pula bahwa penghuni pertama Gumi Sasak (Pulau Lombok) empat puluh jin yang menjelma sebagai manusia. Hal ini terungkap pada data berikut.

(30) Tersebutlah putri jin yang bernama Dewi Anjani. Jin itu sangat cantik dan sakti. Kesaktiannya tidak ada tandingannya di dunia ini. Dewi Anjani merupakan raja semua jin yang berada di Gunung Rinjani. Ia memiliki kesaktian yang bernama Manuk Beri (ayam sakti milik Dewi Anjani). Setiap hari Manuk Beri itu berbunyi. Bila ia mengais tanah, bumi Lombok ini semakin luas. Pada zaman dahulu pulau Lombok ini sunyi senyap, dipenuhi hutan belantara yang lebat, ditumbuhi pohon kayu yang besar-besar sehingga penuh sesak. Itulah sebabnya pulau ini bernama Sasak, karena penuh Sasak dengan pohon kayu. Agar pulau ini berpenghuni, Dewi Anjani memerintahkan sebanyak 40 orang bangsawan jin akan menjelma menjadi manusia dan turun menghuni pulau Lombok ini. Seorang di antaranya diangkat menjadi penghulu dan diberi nama penghulu Alim (DM,1978:25).

Melalui data di atas dapat dipahami, bahwa manusia Sasak percaya dan mengakui adanya mahluk halus yang bernama jin. Jin ini dilukiskan juga memiliki kesaktian sebagaimana manusia. Berdasarkan data di atas diketahui pula bahwa asal mula penghuni pulau Lombok (Gumi Sasak) ini adalah empat puluh bangsawan jin yang menjelma sebagi manusia. Berdasarkan cerita tersebut, manusia jelmaan jin inilah yang turuntemurun menghuni Pulau Lombok. Seperti telah dijelaskan sebelumnya, jin diyakini ada yang baik dan ada pula yang jahat. Jin yang baik, diyakini sering menolong manusia yang dalam kesulitan. Hal ini terlihat ketika Penghulu Alim berusaha melenyapkan putranya sendiri (Doyan Mangan). Ia ingin melenyapkan putranya karena malu dengan kerakusannya. 
Bagaimana caranya melenyapkan Doyan Mangan dan bagaimana upaya pertolongan yang diberikan jin Dewi Anjani? Hal ini terungkap pada data berikut.

(31) Karena sangat marah, penghulu Alim berniat membunuhnya.... Oleh karena itu, diajaknyalah Doyan Mangan pergi ke hutan untuk menebang pohon kayu. Pohon kayu yang akan ditebang sangat besar (pohon ipil). Ketika pohon kayu akan tumbang, diperintahkannyalah Doyan Mangan.... menunjang pohon kayu yang akan tumbang itu.... Dengan segera Doyan Mangan menunjang pohon yang sedang tumbang. Hancurlah tubuh Doyan Mangan ditindih pohon yang besar itu (DM, 1978).

Peristiwa yang menimpa Doyan Mangan ini membuat ibunya selalu menangis. Tangis ibu Doyan Mangan yang sangat menghiba itulah membuat Dewi Anjani (Raja jin gunung Rinjani) menolong Doyan Mangan. Hal tersebut terungkap dalam data berikut.

(32) Dewi Anjani mendengar tangis ibunya Doyan Mangan yang menhiba karena anaknya belum pulang hingga larut malam. Maka diperintahnyalah Manuk Beri yang sekati itu.

"Hai Manuk Beri, pergilah! Cari Mayat Doyan Mangan. Bawalah Bayu Urip ini. Percikanlah mayatku." Terbanglah Manuk Beri itu ke angkasa, sehingga terlihat olehnya pohon ipil yang roboh di tengah hutan dan mayat Doyan Mangan yang berada di bawah pohon itu. Kemudian di kelilingi mayat Doyan Mangan dan dipercekinya dengan Bayu Urip. Dengan seketika Doyan Mangan hidup dan pikulnyalah pohon ipil yang roboh itu.... (DM,1978:27-28).

Data di atas menunjukan, bahwa jin juga ada yang memiliki perangai baik, seperti menolong manusia yang sedang dalam kesulitan atau musibah. Terketuknya hati Dewi Anjani untuk menolong Doyan Mangan yang ditindih pohon besar, melukiskan bahwa jin dipercayai suka menolong manusia yang sedang dalam kesulitan. Perlu dijelaskan bahwa pertolongan yang diberikan jin Dewi Anjani bukan hanya sekali, tetapi setiap kali Doyan Mangan dibunuh oleh orang tuanya (Penghulu Alim).

Kecuali ada jin yang bersifat baik (suka menolong manusia), ada juga jin yang dilukiskan jahat. Jin jahat ini tampak menakutkan, menyeramkan, dan suka memangsa manusia. Untuk mengetahui sosok jin yang jahat (menurut keyakinan manusia Sasak), perhatikan kutipan berikut. Datuq Jabut adalah mahluk gaib yang menjaga hutan Lengkukun. Rambutnya panjang menyapu tanah, matanya besar dan bersinar seperti cahaya lampu petromaks (DL, 1981:30-31). Datuq Jabut diyakini sebagai makhluk supermatural (raja jin). Datuq Jabut adalah makhluk gaib yang menjaga hutan Lengkukun. Berdasarkan data (32) tersebut, jin yang jahat antara lain bentuk visualnya melakukan, berrambut panjang, hingga menyapu tanah, bermata besar dan bersinar bagaikan lampu petromaks. Visualisasi tersebut mencitrakan bahwa Datuq Jabut (sebagai jin jahat) memang tampak angker dan menakutkan.

Berdasarkan analisis tersebut, tergambar bahwa manusia Sasak percaya dahulu juga percaya ada makhluk rohaniah, yaitu makhluk yang tidak mempunyai nafsu, tidak memerlukan makanan dan minuman, dan tidak berjenis kelamin laki-laki dan perempuan. Makhluk rohaniah ini di dalam Islam disebut malaikat. Kepercayaan dan keyakinan kepada makhluk Tuhan yang bernama malaikat ini, terungkap dalam salah satu CRS yang diduga lahir setelah masuknya Islam di Lombok. Cerita tersebut berjudul "Haji Ali Batu" Di dalam cerita ini, tokoh cerita (Haji Ali Batu) menyakini 
adanya malaikat. Hal ini terungkap pada kutipan berikut.

(33) Di saat itu timbullah firasat pada pikiran Haji Ali Batu, bahwa burung itu sebenarnya penjelmaan malaikat, yang sengaja datang untuk menolong dirinya. Karena sewaktu selesai melepaskan ikatanya, burung itu lenyap seketika, pergi entah kemana (HAB, 1981:56).

Percaya kepada malaikat merupakan salah satu rukun iman dalam Islam. Di dalam ajaran Islam malaikat adalah makhluk yang diciptakan dari cahaya. Ia dikaruniai akal, tetapi tidak diberi nafsu. Ia tidak lakilaki atau perempuan. Malaikat sewaktuwaktu bisa mengubah dirinya, seperti bisa menjelma sebagai anak kecil, bisa seperti pemuda, bisa seperti orang tua, bisa berubah menjadi gadis cantik, dan sebagainya. Atas dasar inilah tampaknya Haji Ali Batu mencurigai burung besar yang yang membawanya terbang sampai di Afrika itu, sebagai jelmaan malaikat.

\subsection{Eksistensi Kepercayaan Masyarakat Sasak Sekarang terhadap Masalah Supranatural}

Bentuk-bentuk kepercayaan terhadap masalah supranatural dalam CRS seperti telah disajikan pada subbab (4.1) berdasarkan pengamatan peneliti terhadap perilaku masyarakat Sasak, khususnya yang tinggal di sekitar desa peneliti masih eksis hingga saat ini. Hanya intensitas kepercayaan masyarakat Sasak saat ini terhadap hal-hal ghaib (di luar perkara gaib terkait dengan Wali Allah, Malaikat, dan Jin) sudah berkurang.

Kepercayaan terkait adanya Waliyullah dan Keramat Wali sejak dahulu hingga saat ini masih tetap ada. Cerita tentang Wali Allah yang bernama Gaos Abdul Razak dan Wali Nyatoq, bukan saja ada dalam cerita lisan (cerita rakyat yang telah didokumentasikan), tetapi hingga sekarang masih hidup dibuktikan dengan kecintaan mereka yang diwujudkan dalam bentuk memelihara maqam para wali tersebut dan menziarahinya ketika mereka punya hajat tertentu.

Salah satu contoh konkret keyakinan terhadap masalah karomah/keramat wali ini secara nyata ditemukan di masyarakat Sasak sekarang, misalnya berduyun-duyunnya masyarakat menziarahi maqam/kuburan ulama yang diyakini sebagai waliyullah, seperti maqam syeikh Zainuddin di Pancor, kuburan sosok yang diyakini "Penghulu Selaparang" di Selaparang, dan makam tokoh lainnya yang oleh masyarakat Sasak distilahkan dengan ziarah makam sembilan.

Beberapa masalah supranatural yang telah disajikan, seperti bertapa untuk mendapatkan kesaktian, kepercayaan kepada wangsit, firasat, dan mimpi, dan kepercayaan kepada kekuatan makhluk halus (jin dan malaikat) masih eksis hingga saat ini.

Eksistensi kepercayaan terhadap masalah-masalah ghaib tersebut, seperti bertapa, masih eksis dilakukan masyarakat Sasak. Contohnya, di Desa Wanasaba terdapat satu kuburan (Makam Bru) sering dijadikan tempat bertapa untuk mendapatkan kesaktian atau untuk tujuan lainnya. Begitu juga dengan "kegemaran" mengunjungi paranormal masih banyak dilakukan hingga sekarang. Contoh di tempat penulis, tidak jarang masyarakat datang ke dukun/paranormal meminta petunjuk terkait dengan perjodohan, nasibnya di masa mendatang kalau dia menikah dengan seseorang, juga tentang akan diangkat/tidaknya mereka menjadi pejabat di suatu daerah, dan berbagai keperluan lainnya.

Di Wanasaba, masih banyak masyarakat mendatangi orang yang dianggap "pintar" melihat hal-hal yang akan terjadi. Contohnya, kalau mereka ingin melaksanakan pesta (nikah atau pesta 
lainnya), mereka meminta petunjuk tentang hari apa sebaiknya pesta itu dilaksanakan. Begitu juga dengan penentuan bulan dan hari apa mereka menikah, juga masih meminta pendapat orang tertentu yang dianggap "pintar".

Kepercayaan masyarakat Sasak yang tercermin dalam cerita rakyat Sasak yang juga masih eksis hingga sekarang adalah "kepercayaan kepada takhayul". Contoh konkret keyakinan ini, misalnya di Wanasaba, Lombok Timur sebagian masyarakat ketika akan membangun rumah atau bangunan tertentu, mereka menaruh benda-benda tertentu (ketupat lepas) yang mereka taruh di pojok-pojok rumah. Hal ini mereka yakini supaya terhindar dari gangguan makhluk halus (Syaitan dan jin) jahat.

Contoh lainnya, jika seorang anak kecil (bayi) dibawa ke suatu tempat yang agak jauh dari tempatnya, orang tua mereka menorehkan tanah di tempat yang dikunjungi di dahi anak tersebut. Hal ini diyakini dapat menolak pengaruh buruk yang ada di tempat itu.

Begitu juga dengan keyakinan terkait dengan pengaruh makhluk halus, masih hidup di masyarakat Sasak. Misalnya, ketika ada peristiwa kesurupan, masyarakat mencari orang yang dianggap bisa mengusir makhluk halus tersebut (jin/syetan). Keyakinan terhadap jin/syetan ini ada di setiap tempat, misalnya di Desa Wanasaba, Pancor, Korleko, dan berbagai tempat lainnya. Hal ini tentu saja eksis karena adanya pengaruh makhluk halus (jin, syetan) ini diperoleh langsung dari ajaran agama Islam.

Jadi, beberapa masalah supranatural yang telah disajikan, seperti bertapa untuk mendapatkan kesaktian, kepercayaan kepada wangsit, firasat, dan mimpi, dan kepercayaan kepada kekuatan makhluk halus (jin dan malaikat) masih eksis hingga saat ini. Eksistensi kepercayaan terhadap masalah-masalah ghaib tersebut, tampak pada "kegemaran" bertapa, mengunjungi paranormal/dukun, berbagai bentuk kepercayaan terhadap takhayul. Kepercayaan manusia kepada para ahli nujum (paranormal), menggambarkan keyakinan masyarakat terhadap kebenaran ramalan. Keyakinan itu dimanifestasikan dalam berbagai hal, misalnya meminta bantuan ahli nujum untuk menentukan obat dari suatu penyakit, meminta pendapat pada ahli nujum dalam menentukan lokasi terbaik untuk mendirikan sebuah kerajaan, dan memanfaatkan para ahli nujum dalam memecahkan rahasia (misteri) yang akan menimpa suatu kerajaan, dan sebagainya.

Satu hal yang perlu ditegaskan, bahwa meskipun persoalan supernatural ini masih eksis di masyarakat Sasak, namun karena pergeseran nilai dan akibat kemajuan ilmu pengetahuan dan teknologi, keyakinan ini semakin mengalami degradasi. Sebagian kecil saja masyarakat meyakini kesaktian lewat bertapa. Masalah keyakinan kepada makhluk halus, seperti pertolongan dan gangguan jin dan juga malaikat, hingga saat ini masyarakat secara masif masih meyakini. Hal ini tentu saja karena keyakinan kepada dua makhluk ghaib tersebut bersumber dari ajaran agama (Islam) yang dianut oleh masyarakat Sasak.

\section{Penutup}

Dari analisis dan pembahasan yang telah dilakukan dapat disimpulkan, bahwa cerita rakyat Sasak banyak mengungkapkan keyakinan masyarakat Sasak pada masa lampau mengenai hal-hal yang bersifat supranatural. Masalah supranatural yang mereka yakini, yaitu: (1) kepercayaan terhadap adanya Wali Allah, (2) kepercayaan kepada wangsit, firasat, dan mimpi, dan (3) kepercayaan kepada kekuatan makhluk halus (jin dan malaikat). Kepercayaan terhadap masalah-masalah ghaib tersebut, selanjutnya melahirkan 
"kegemaran" bertapa, mengunjungi para normal, berbagai bentuk kepercayaan terhadap takhayul. Kepercayaan manusia kepada para ahli nujum (paranormal), menggambarkan keyakinan masyarakat Sasak terhadap kebenaran ramalan. Keyakinan itu dimanifestasikan dalam berbagai hal, misalnya meminta bantuan ahli nujum untuk menentukan obat dari suatu penyakit, meminta pendapat pada ahli nujum dalam menentukan lokasi terbaik untuk mendirikan sebuah kerajaan, dan memanfaatkan para ahli nujum dalam memecahkan rahasia (misteri) yang akan menimpa suatu kerajaan, dan sebagainya.

Sejalan dengan hasil analisis dan pembahasan di atas, disarankan kepada pembaca, khususnya masyarakat suku Sasak supaya melakukan pengkajian lebih lanjut terhadap folklor-folklor lisan Sasak yang telah didokumentasikan. Hal ini penting dilakukan supaya kita lebih banyak tahu pola-pola pikir orang-orang tua Sasak masa lampau dan lebih memahami nilai-nilai luhur budaya lokal agar kita dapat merekonstruksi pemikiran masyarakat masa lampau dan dan menyesuaikannya denan perkembanan zaman.

\section{Daftar Pustaka}

Abrams, M.H. 1988. A Glossory of Literary Terms. USA: Holt, Rinerart and Winston, Inc.

Ati, S.R. 1992. Dewi Rengganis. Jakarta: Pusat Binaan dan Pengembangan Bahasa Departemen Pendidikan dan Kebudayaan.

Aminuddin (Ed.). 1990a. Pengembangan Penelitian Kualitatif dalam Bidang Bahasa dan Sastra. Diterbitkan Atas Kerja Sama HISKI Komisariat
Malang dengan Yayasan Asih Asah Asuh (YA3) Malang.

- 1990b. Sekitar Masalah Sastra, Beberapa Prinsip, dan Model Pengembannya. Yayasan Asih Asah Asuh (YA3) Malang.

Aminuddin 1998. Paradigma Konstruktivis dalam Penelitian Tradisi Lisan Sunan Giri di Gersik Jawa Timur. Makalah disajikan dalam Lokakarya Metodologi Kajian Tradisi Lisan, Bogor 8-11 Juni.

Bogdan, R.C. dan Knoop, Biklen.1992. Qualitatif Research for Education, Introduction to Theory and Methods. Allyn and Bacon, Boston, London, Toronto, Sydney, Tokyo, Singapore.

Dhavamony, M. 1995. Fenomenologi Agama. Yogyakarta: Kanisius.

Danandjaya, J. 1991a. Folklor Indonesia, Ilmu Gosip, Dongeng, dan lain-lain. Jakarta: Graffiti.

- 1991b. Metode Kualitatif dalam Bidang Folklor. Dalam Aminuddin (Ed.), Pengembangan Metode Kualitatif dalam Bidang Bahasa dan Sastra (hlm. 96-107) Malang: Himpunan Sarjana Kesusastraan Komisariat Malang dan YA3.

Depdikbud. 1977/1978. Adat Istiadat Daerah Nusa Tenggara Barat. Proyek Penelitian dan Pencatatan Kebudayaan Daerah.

Depdikbud. 1981. Cerita Rakyat Nusa Tenggara Barat (Mite dan Legende). Proyek Penerbitan dan Pencatatan Kebudayaan Daerah. 
Depdikbud. 1982. Cerita Rakyat Nusa Tenggara Barat. Jakarta: Proyek Inventarisasi dan Dokumentasi Kebudayaan Daerah.

Depdikbud. 1992. Peralatan Hiburan dan Kesenian Tradisional Daerah Nusa Tenggara Barat.

Fakihuddin, Lalu. 1998. Citra Manusia dan Nilai-nilai Edukatif dalam Cerita Rakyat Sasak. (Thesis). IKIP Malang, Program Pascasarjana, Program Studi Pendidikan Bahasa dan Sastra Indonesia.

Pusat Pembinaan dan Pengembangan Bahasa (PPPB). 1993. Sastra Daerah di Nusa Tenggara Barat: Analisis Tema, Amanat dan Nilai Budaya. Jakarta: Pusat Pembinaan dan Pengembangan Bahasa, Depdikbud.

Moleong, L.J. 1995. Metode Penelitian Kualitatif. Bandung: PT Remaja Rosdakarya.

Miles, M.B. \& Huberman, A.M. 1984. Qualitative Data Analysis. Beverly Hill: Sage Publications.

Poerwadaminta, W.J.S. 1986. Kamus Umum Bahasa Indonesia. Jakarta: Balai Pustaka.

Polak, J.B.A.F. 1985. Sosisologi Suatu Pengantar Ringkas. Jakarta: PT Ichtiar Baru Van Hoeve.

Purwatha, M.P. 1990. Nilai-Nilai Budaya Bali Nusa Tenggara Barat. Makalah tidak diterbitkan. Jakarta: Pusat Pembinaan dan Pengembangan Bahasa.
Pusat Pembinaan dan Pengembangan Bahasa. 1995. Kamus Besar Bahasa Indonesia.

Rakhmat, J. 1991. Renungan-Renungan Sufistik (Membuka Tirai Kegaiban). Bandung: Penerbit Mizan.

Robson, S.O. 1994. Prinsip-Prinsip Filologi Indonesia. Jakarta: RUL.

Rusyana, Y. 1982/1983. "Usaha Penyebarluasan Tradisi Lisan”. Analisis Kebudayaan. III (2): 29-35.

Saidi, S., Thoir, N., Bagus, I.G.N. 1987. Sastra Lisan Sasak. Jakarta: Pusat Pembinaan dan Pengembangan Bahasa Departemen Pendidikan dan Kebudayaan.

Santosa, P. 1993. Ancangan Semiotika dan Pengkajian Susastra. Bandung: Angkasa.

Semi, M.A. 1990. Metode Penelitian Sastra. Bandung: Angkasa.

Shipley, J.T. 1962. Dictionary of World Literatur. Littlefield, Adams \& Co Patterson, New Jersy.

Simanjuntak, Herpinus. 1997. Kamus Sinonim Antonim. Jakarta: Kesaint Blane.

Soemardjo, J. 1984. Memahami Kesusastraan. Bandung: Alumni.

Sudjiman, P. 1990. Kamus Istilah Sastra. Jakarta: Penerbit Universitas Indonesia (UI-Press).

Tim Direktorat Sejarah dan Nilai Tradisional. 1980. "Manfaat Pengumpulan Cerita Rakyat dalam 
...Suatu Kajian Tematis Terhadap Cerita Rakyat...(Lalu Fakkihuddin) $\mid \mathbf{1 2 3}$
Rangka
Penyelamatan
dan
Pemeliharaan Warisan Budaya."
Majalah Analaisis Kebudayaan, 1 (1):
65-71.

http://en.wiktionary.org/wiki/supernatural).

http://oxforddictionaries.com/definition/ame rican_english/supernatural) 